\section{Small Divisions of Ornamental Grasses Produce the Best Growth Following Direct Potting}

\author{
Mark H. Brand \\ Department of Plant Science, U-67, University of Connecticut, Storrs, \\ CT 06269-4067
}

Additional index words. Calamagrostis $\times$ acutiflora, Miscanthus oligostachyus, Miscanthus sinensis, Panicum virgatum, Pennisetum alopecuroides

\begin{abstract}
Potting of bare-root spring divisions is a simplified approach to ornamental grass production. Large and small divisions of eight common ornamental grasses were directly potted into 7-L nursery containers and grown outdoors for 20 weeks to determine an appropriate division size for each grass. Response to division size was dependent on the grass species. Large divisions of Calamagrostis xacutiflora 'Karl Foerster' (Schräd.) produced twice as many inflorescences as small divisions. At harvest, large divisions of Miscanthus oligostachyus 'Purpurascens' (Stapf.) had twice as many inflorescences and 1.5 times as many tillers as small divisions. However, new tiller production in large divisions was only $50 \%$ of that in small division plants. Large divisions of Miscanthus sinensis (Anderss.) cultivars produced more tillers and greater fresh and dry weights than did small divisions, but again, the differences were not proportional to the size difference between the initial divisions. Large divisions of Panicum virgatum (L.) produced 50 more tillers per plant than did small divisions, but plant weight, size, and number of inflorescences were not affected by division size. Plants from large divisions of Pennisetum alopecuroides (L.) Spreng. were $7 \mathrm{~cm}$ shorter than small divisions and produced $24 \%$ more inflorescences and $\mathbf{2 7 \%}$ more tillers, but appeared nutrient and/or water stressed. For most grasses, smaller division size is recommended for direct spring potting.
\end{abstract}

Home gardeners and landscape professionals use ornamental grasses because they are suited to a wide range of landscape situations. Furthermore, their unique height, shape, texture, motion, and foliage colors make them useful additions to contemporary landscapes. The increased awareness of the value of ornamental grasses in landscape horticulture has made production of these plants in commercial nurseries economically important (Rhodus, 1995). Despite the popularity of ornamental grasses, knowledge regarding their cultural requirements and nursery production is limited. This poor understanding is due, in part, to a low level of scientific inquiry into ornamental grass production. As a consequence, growers have difficulty producing and marketing grasses as effectively as other groups of plants.

Ornamental grass research has focused on micropropagation (Gawel et al., 1990; Robacker and Corley, 1992), growing temperature (Lavis-Ham, 1993), potting medium (Meza Discua, 1995), and seed germination (Watkinson and Pill, 1998). These studies have been conducted on a limited number of species, especially given the large number of genera of grasses grown as ornamentals. Most

Received for publication $17 \mathrm{Feb} .1999$. Accepted for publication 30 Mar. 1999. Storrs Agricultural Experiment Station scientific contribution 1874. I thank Duncan McDougal for donating the plants used in this research. The cost of publishing this paper was defrayed in part by the payment of page charges. Under postal regulations, this paper therefore must be hereby marked advertisement solely to indicate this fact. grasses are propagated by division to preserve cultivar identity and because this method has a high success rate (Corley, 1989; Simon, 1982). However, ornamental grasses can also be propagated by seed or cuttings, depending on the species or cultivar involved (Barnes, 1994; Corley, 1989; Gibson, 1986; Simon, 1982).

In many nurseries, ornamental grasses are potted in May, using plugs or liners started the previous October/November (for cool-season grasses), or in February (for warm-season grasses). Although this system makes efficient use of a small number of stock plants to yield a large number of liners, it requires more specialized production methods not needed when larger divisions are direct-potted in the spring. Liner production adds cost because it requires more man-hours, skilled laborers, fuel to heat greenhouses, and specialized facilities.

This research examined the performance of common ornamental grasses when two division sizes were used in a spring, directpotting system that eliminates the necessity for liner production.

\section{Materials and Methods}

Plant material. Field-grown plants of Calamagrostis ×acutiflora 'Karl Foerster' (Schräd.), Miscanthus oligostachyus 'Purpurascens' (Stapf.), Miscanthus sinensis (Anderss.) 'Graziella', M. sinensis 'Silberfeder', M. sinensis 'Strictus', M. sinensis 'Variegatus', Panicum virgatum (L.), and Pennisetum alopecuroides (L.) Spreng. were dug in late April and used as the source of divisions. Following digging, grasses were held in a cold frame prior to division. For each grass, two division sizes, large and small, were made on 9 May 1995 as follows: C. $\times$ acutiflora 'Karl Foerster' ( small = 15-20 tillers, $3 \times 5-\mathrm{cm}$ clump, large $=35-40$ tillers, $5 \times 10$-cm clump); M. oligostachyus 'Purpurascens' (small $=12$ 15 tillers, $7 \times 7-\mathrm{cm}$ clump, large $=45-50$ tillers, $12 \times 12-\mathrm{cm}$ clump); M. sinensis 'Graziella' (small = 4-6 tillers, $5 \times 5-\mathrm{cm}$ clump, large $=15-20$ tillers, $10 \times 10$-cm clump); M. sinensis 'Silberfeder' ( small $=3-5$ tillers, 5 $\times 5$-cm clump, large $=8-12$ tillers, $12 \times 12-\mathrm{cm}$ clump); $M$. sinensis 'Strictus' (small $=3-5$ tillers, $5 \times 5$-cm clump, large $=9-11$ tillers, 10 $\times 10-\mathrm{cm}$ clump); M. sinensis 'Variegatus' $($ small $=4-6$ tillers, $5 \times 7$-cm clump, large $=$ $12-15$ tillers, $10 \times 10-\mathrm{cm}$ clump); $P$. virgatum (small $=$ undetermined number of tillers, $5 \times 5$ $\mathrm{cm}$ clump, large $=$ undetermined number of tillers, $10 \times 10$-cm clump); $P$. alopecuroides (small $=12-15$ tillers, $3 \times 4-\mathrm{cm}$ clump, large $=$ 25-30 tillers, $5 \times 7$-cm clump). Tiller number and clump size chosen for each grass were based on propagation practices observed at several nurseries and knowledge of growth potential and habit. Divisions were made by washing the soil from the grass crowns, trimming roots to $\approx 8 \mathrm{~cm}$, and cutting through the crown with a large knife.

Growing conditions. All divisions were potted directly into 7-L containers (Classic 600; Nursery Supplies, Fairless Hills, Pa.) on 10 May 1995. The potting medium was 3 pine bark : 2 sphagnum peatmoss : 1 sand (by volume) amended with dolomitic limestone at $5.75 \mathrm{~kg} \cdot \mathrm{m}^{-3}$. Following planting, containers were topdressed with Sierrablen $17 \mathrm{~N}-2.6 \mathrm{P}$ $8.3 \mathrm{~K}$ plus micronutrients 8 - to 9 -month formulation (The Scotts Co., Marietta, Ga.), at 40 g per plant. Plants were grown in an outdoor, gravel-surfaced, container nursery with full sun exposure. In addition to precipitation, irrigation was provided by a trickle system and the volume of water delivered was increased throughout the season to match increased water demands resulting from plant growth. Each plant received a single application of $2 \mathrm{~L}$ of water daily from 10 May to 30 June, $2 \mathrm{~L}$ of water twice daily (total of $4 \mathrm{~L}$ daily) between 1 July and 31 July, and 2 L three times daily (total of $6 \mathrm{~L}$ daily) from 1 Aug. to 27 Sept. In this research, no herbicides or pesticides were used; plants were hand weeded.

Data collection. At the end of the growing season, data were collected to determine how well small and large divisions performed in a direct pot system. Plant harvest and quantification began 27 Sept. and required $8 \mathrm{~d}$ to complete. Since M. sinensis 'Strictus' and 'Variegatus' were the latest blooming plants in the study, they were harvested last to afford these cultivars more time to bloom. Plant and inflorescence heights were measured from the potting medium surface to the highest vertical point reached by either the foliage or the inflorescences, respectively. Overarching leaves were not extended during measurement. Plant width was measured twice, at right angles to each other, and average plant width was calculated. Culms were counted as flow- 
Table 1. The response of small and large dormant divisions of eight ornamental grasses to direct spring potting.

\begin{tabular}{|c|c|c|c|c|c|c|c|c|c|}
\hline \multirow{3}{*}{$\begin{array}{l}\text { Division } \\
\text { size }(\mathrm{cm})\end{array}$} & \multirow{3}{*}{$\begin{array}{l}\text { No. of } \\
\text { tillers }\end{array}$} & \multicolumn{8}{|c|}{ Mean $^{2}$} \\
\hline & & \multirow{2}{*}{$\begin{array}{l}\text { Foliage } \\
\text { ht }(\mathrm{cm})\end{array}$} & \multirow{2}{*}{$\begin{array}{c}\text { Inflorescence } \\
\text { ht }(\mathrm{cm})\end{array}$} & \multirow{2}{*}{$\begin{array}{c}\text { Plant } \\
\text { width }(\mathrm{cm})^{\mathrm{y}}\end{array}$} & \multirow{2}{*}{$\begin{array}{c}\text { Plant size } \\
\left(\mathrm{dm}^{3}\right)^{\mathrm{x}}\end{array}$} & \multicolumn{2}{|c|}{ No. of } & \multicolumn{2}{|c|}{ Shoot mass (g) } \\
\hline & & & & & & Inflorescences & Tillers & Fresh & Dry \\
\hline \multicolumn{10}{|c|}{ Calamagrostis $\times$ acutiflora 'Karl Foerster' } \\
\hline $3 \times 5$ & $15-20$ & 80 & 131 & 21.9 & 38.1 & 8.4 & 96.3 & 216 & 82 \\
\hline $5 \times 10$ & $35-40$ & 86 & 141 & 20.7 & 38.0 & 19.0 & 114.0 & 237 & 102 \\
\hline Significance of $\mathrm{F}$ & & NS & $*$ & NS & NS & $* * *$ & NS & NS & $*$ \\
\hline \multicolumn{10}{|c|}{ Miscanthus oligostachyus 'Purpurascens' } \\
\hline $7 \times 7$ & $12-15$ & 102 & 137 & 16.7 & 28.0 & 15.5 & 60.1 & 397 & 163 \\
\hline $12 \times 12$ & $45-50$ & 99 & 141 & 20.1 & 39.9 & 29.2 & 92.7 & 480 & 209 \\
\hline Significance of $\mathrm{F}$ & & NS & NS & $* * *$ & $* * *$ & $* *$ & $* * *$ & $*$ & $* *$ \\
\hline \multicolumn{10}{|c|}{ Miscanthus sinensis 'Graziella' } \\
\hline $5 \times 5$ & $4-6$ & 120 & 166 & 15.3 & 27.6 & 20.6 & 39.0 & 533 & 202 \\
\hline $10 \times 10$ & $15-20$ & 110 & 164 & 16.9 & 31.1 & 26.6 & 61.6 & 606 & 229 \\
\hline Significance of $\mathrm{F}$ & & NS & NS & NS & NS & $* *$ & $* * *$ & $*$ & $*$ \\
\hline \multicolumn{10}{|c|}{ Miscanthus sinensis 'Silberfeder' } \\
\hline $7 \times 7$ & $3-5$ & 134 & 169 & 18.8 & 47.6 & 7.3 & 35.6 & 628 & 219 \\
\hline $12 \times 12$ & $8-12$ & 139 & 184 & 19.8 & 54.2 & 11.0 & 42.7 & 676 & 260 \\
\hline Significance of $\mathrm{F}$ & & NS & $*$ & NS & NS & $*$ & $*$ & $*$ & $*$ \\
\hline \multicolumn{10}{|c|}{ Miscanthus sinensis 'Strictus' } \\
\hline $5 \times 5$ & $3-5$ & 141 & 132 & 16.8 & 38.4 & 1.9 & 33.0 & 378 & 118 \\
\hline $10 \times 10$ & $9-11$ & 146 & 144 & 18.7 & 48.9 & 2.7 & 42.4 & 507 & 171 \\
\hline Significance of $\mathrm{F}$ & & NS & NS & NS & NS & NS & $*$ & $* *$ & $* * *$ \\
\hline \multicolumn{10}{|c|}{ Miscanthus sinensis 'Variegatus' } \\
\hline $5 \times 7$ & $4-6$ & 121 & 117 & 15.6 & 29.5 & 1.1 & 31.7 & 423 & 134 \\
\hline $10 \times 10$ & $12-15$ & 126 & 123 & 15.8 & 30.6 & 1.1 & 45.4 & 541 & 180 \\
\hline Significance of $\mathrm{F}$ & & NS & NS & NS & NS & NS & $* *$ & $* *$ & $* * *$ \\
\hline \multicolumn{10}{|c|}{ Panicum virgatum } \\
\hline $5 \times 5$ & undet. & 84 & 118 & 21.7 & 39.6 & 88.3 & 140.1 & 480 & 160 \\
\hline $10 \times 10$ & undet. & 83 & 120 & 23.1 & 44.1 & 82.8 & 188.7 & 459 & 161 \\
\hline Significance of $\mathrm{F}$ & & NS & NS & NS & NS & NS & $* *$ & NS & NS \\
\hline \multicolumn{10}{|c|}{ Pennisetum alopecuroides } \\
\hline $3 \times 4$ & $12-15$ & 93 & 109 & 19.2 & 34.3 & 35.7 & 88.6 & 531 & 165 \\
\hline $5 \times 7$ & $25-30$ & 86 & 106 & 20.7 & 36.7 & 44.3 & 112.8 & 528 & 180 \\
\hline Significance of $\mathrm{F}$ & & $*$ & NS & $*$ & NS & $*$ & $* *$ & NS & NS \\
\hline
\end{tabular}

${ }^{\mathrm{z}} \mathrm{n}=10$ plants.

yPlant width is the mean of two plant widths taken at right angles to each other at the crown.

xPlant size is the product of the two plant widths taken at right angles to each other and foliage height.

ss, *,**,*** Significant at $P \leq 0.05,0.01$, or 0.001 , respectively.

ering if any part of the floral structure was visible at the time of harvest. Tillers (shoots) were counted if they extended $3 \mathrm{~cm}$ or more from the potting medium surface. Buds at or below the surface, representing next-year's shoot growth, were not counted in this study. Shoot weight was determined as a combination of weights of all floral and vegetative culms removed above the potting medium surface.

Experimental design and statistical analysis. The study was arranged as a randomized complete-block design with 10 replications per cultivar and division size combination. One-way analysis of variance was conducted on each type of grass, because large and small division sizes and tiller numbers varied based on the species or cultivar of grass involved. Means were separated using an $\mathrm{F}$ test.

\section{Results and Discussion}

All of the grasses tested in this study survived and performed well in a direct potting system, producing salable plants in 2-gallon containers by the end of the growing season or earlier. Vigorous grasses, including $M$. oligostachyus 'Purpurascens', P. virgatum, and $P$. alopecuroides developed into large, marketable plants following only 12 weeks of growth. Visual observation of the plants at the end of the growing season indicated that plants produced by direct potting of field divisions were no more variable than plants grown from greenhouse-produced liners observed at commercial nurseries.

Large divisions were important for inflorescence production on $C$. Xacutiflora 'Karl Foerster' (Table 1). More than twice as many inflorescences were produced by large divisions as by small divisions and they were taller. Large divisions of $C$. ×acutiflora 'Karl Foerster' had greater dry weight than, but equivalent fresh weight to small divisions, because this cool-season species blooms in June and develops dried flowering culms by the end of July in U.S. Dept. of Agriculture (USDA) hardiness zone 5. At harvest, the flowering culms, which were included in the shoot weights, were completely dried and tancolored, therefore, contributing similar values to both fresh and dried weights. Plants from large divisions had underrepresented fresh weight in comparison with plants from small divisions, because they produced many more flowering culms. Division size did not affect foliage height, inflorescence height, plant width, plant size, number of tillers, or fresh weight for 'Karl Foerster'.

Large and small divisions of M.oligostachyus
'Purpurascens' varied for all plant measurements except foliage and inflorescence height (Table 1). Large divisions produced twice as many inflorescences as did small divisions and 1.5 times the number of tillers. However, small division plants produced between four and five new tillers per initial tiller, while large divisions only produced about two new tillers per initial tiller. Similarly, large divisions produced about 0.6 inflorescence per initial tiller, while small divisions produced over one inflorescence per initial tiller. Plant width, plant size, and fresh and dry weights for large division plants were 1.2 to 1.4 times as large as those recorded for small division plants. However, large divisions were about three times as large as small divisions at the time of potting, indicating further that they were less efficient at increasing in size than were small divisions.

All cultivars of $M$. sinensis behaved similarly in response to division size (Table 1). Plants from large divisions of all M. sinensis cultivars produced more tillers and greater fresh and dry weights than did plants from small divisions. However, as was observed for M. oligostachyus 'Purpurascens', increases in plant weight or tiller number resulting from use of large divisions were not proportional to the difference in size of the starting divisions. Initially, large divisions were about two to 
three times as large as small divisions, but at harvest, large-division plants had shoot weights 1.2-1.6 times as great as those of small division plants. Furthermore, small divisions generally produced twice as many new tillers per original tiller as did large divisions.

Large divisions of $M$. sinensis 'Graziella' and 'Silberfeder' produced more inflorescences at harvest than did small divisions (Table 1). Inflorescences of $M$. sinensis 'Silberfeder' were taller on large divisions than on small divisions. Differences in number of inflorescences per plant were not detected between large and small divisions of $M$. sinensis 'Strictus' and 'Variegatus', perhaps because both are lateblooming cultivars. In USDA hardiness zone 5 landscapes, these cultivars do not bloom heavily until mid-October. Foliage height, plant width, and plant size did not differ between large and small divisions of any of the $M$. sinensis cultivars studied.

Growth of switchgrass ( $P$. virgatum) was too vigorous for a $7-\mathrm{L}$ container when large divisions were potted; plants rapidly filled the containers and exhibited symptoms of nutrient, and possibly moisture, stress. Although large-division plants produced nearly 50 more tillers per plant than did small-division plants, there were no differences in fresh and dry weights, number of inflorescences, foliage height, or inflorescence height (Table 1). This indicates that large-division plants had a greater number of thin, weak tillers than did smalldivision plants. Furthermore, a larger proportion of the tillers produced by large divisions failed to flower; $63 \%$ of the tillers of small divisions flowered, but only $44 \%$ of those of large divisions. Since a primary ornamental feature of $P$. virgatum is its flowering display, the effect of division size on flowering is noteworthy. Growers should be careful to use sufficiently large containers for their switchgrass divisions to insure that a large percentage of culms flower.

Like $P$. virgatum, $P$. alopecuroides is a vigorous grass and large-division plants appeared to be under nutrient and water stress by the end of the growing season. Roots were potbound and plants were difficult to remove from their containers. Large-division plants were $7 \mathrm{~cm}$ shorter and slightly wider than were small-division plants (inflorescences not included), but overall plant sizes were similar (Table 1). Plants of both division sizes produced inflorescences on $\approx 40 \%$ of the tillers, but large division plants produced $24 \%$ more inflorescences and 27\% more tillers than did small division plants. The additional tillers and inflorescences on large-division plants are desirable, but their potential for increasing plant marketability may be offset somewhat by the nutrient and water stress symptoms visible on the foliage.

This study demonstrates that direct potting of dormant divisions into 7- $\mathrm{L}$ containers is effective for a range of ornamental grasses. This method may be useful for situations where plant material is plentiful, facilities are limited, and a more simple approach is desired. The effect of division size on plant response was highly dependent on the grass species or cultivar involved. Larger divisions may be useful in significantly enhancing flowering in a grass whose inflorescences are the primary ornamental feature, such as $C$. xacutiflora 'KarlFoerster'. However, for vigorous grasses,
7-L containers may be inadequate for larger divisions, resulting in either a poorer quality plant or simply a waste of plant material that could have been further divided into more propagules. For most of the grasses in this study, smaller divisions can be recommended for direct potting into 7-L containers.

\section{Literature Cited}

Barnes, H.W. 1994. Grasses from cuttings. Proc. Intl. Plant Prop. Soc. 44:543.

Corley, W.L. 1989. Propagation of ornamental grasses adapted to Georgia and the U.S. Southeast. Proc. Intl. Plant Prop. Soc. 39:332-337.

Gawel, N.J., C.D. Robacker, and W.L. Corley. 1990. In vitro propagation of Miscanthus sinensis. HortScience 25:1291-1293.

Gibson, J.D. 1986. Hints for propagating ornamental grasses, azaleas, and junipers. Amer. Nurseryman 164:90-92.

Lavis-Ham, C. 1993. The influence of temperature and container size on the growth of four ornamental grasses. MS Thesis, Dept. of Hort., For. and Rec. Res., Kansas State Univ., Manhattan.

Meza Discua, J.L. 1995. Vegetative propagation of ornamental grasses as influenced by growing media. MS Thesis, Tennessee State Univ., Nashville.

Rhodus, T. 1995. Views on management. Perennial Plants 3:29-38.

Robacker, C.D. and W.L. Corley. 1992. Plant regeneration of pampas grass from immature inflorescences cultured in vitro. HortScience 27:841843.

Simon, R.A. 1982. Propagation of ornamental grasses. Proc. Intl. Plant Prop. Soc. 32:517-521.

Watkinson, J.I. and W.J. Pill. 1998. Gibberellic acid and presowing chilling increase seed germination of indiangrass [Sorghastrum nutans (L.) Nash.]. HortScience 33:849-851. 